\title{
The Influence of $\mathrm{ZnO} / \mathrm{TiO}_{2}$ Nanohybrid Blending on the Ultrafiltration Polysulfone Membranes
}

\author{
STEFAN CATALIN PINTILIE, LAURENTIA GEANINA TIRON, ANDREEA LILIANA LAZAR, MARIA VLAD, IULIAN GABRIEL BIRSAN*, \\ STEFAN BALTA* \\ Dunarea de J os University of Galati, 800008, 47 Domneasca Str., 800008, Galati, Romania
}

\begin{abstract}
In recent years, the inorganic nanoparticles played an important role in the membrane technology due to their special properties, most notably being the hydrophilicity/hydrophobicity modification of the active surface of the membrane. In this paper, the polymer used for membrane manufacturing was polysulfone (PSf) via phase-inversion method. The composite PSf membranes were prepared by blending zinc oxide ( $\mathrm{ZnO})$, titanium dioxide ( $\mathrm{TiO}_{2}$ ) nanoparticles and $\mathrm{ZnO} / \mathrm{TiO}$, nanohybrid with three concentrations. Retention of Congo red dye, distilled water permeability, relative flux and relative flux reduction were tested in order to study the effects of the nanoparticles in the membrane matrix. SEM, EDX, porosity, roughness, contact angle, tensile strength and elongation measurement were conducted in this article, also. Compared with control PSf, ZnO/PSf and TiO.JPSf membranes, the experimental results indicated that the ZnO/TiO./PSf nanohybrid membrane presents the best overall properties, including permeability, retention, and antifouling ability. ZnO/TiO./PSf membrane exhibits a percentage increase in permeability of $254 \%$ and retention of $64.58 \%$ relative to that of the control PSf membrane.
\end{abstract}

Keywords: polysulfone, nanoparticles, $\mathrm{ZnO}, \mathrm{TiO}_{2}, \mathrm{ZnO} / \mathrm{TiO}_{2}$, nanohybrid

Membrane technology have gained popularity over the past decades due to a series of advantages that outperform even conventional treatment units [1], such as ease in construction and maintenance, stability in filtration and water production, high retention of particles and undesirable pathogens in process water as well as minimal production of sludge [2-4]. The materials from which the membrane matrix is made are divided into two main categories: organic and inorganic [5].

Polymeric membranes are more advantageous compared to inorganic membranes in terms of efficiency in fabrication and applicability, lower costs and appropriate robustness $[6,7]$. Due to the ability of modifying the parameters in the manufacturing of organic membranes suitable for a specific field of application, few research has been conducted in order to discover or create a new type of special polymer, thus in preponderance the organic membranes are made of the same polymers, most notably being polyether sulfone (PES), polysulfone (PSf), poly (vinylidene fluoride) (PVDF) and cellulose acetate (CA) [8-10]. Polysulfone is a special polymer which is used at industrial scale for wastewater treatments, with high thermal, chemical and mechanical stability [11-13]. The main drawback for the polysulfone membrane is its low hydrophilicity which causes a stronger interaction with a diversity of solutes that lead to fouling [14].

The main purpose in membrane research is to modify certain parameters, with respect to budget, in order to create the optimal membrane that comprises both permeate flux and retention capacity at maximum level $[15,16]$. Distinct membrane modification methods have been employed to improve the overall performance of membranes of which the most common being blending, grafting, chemical treatment and coating [4, 17]. Of these methods, blending technique, primarily with hydrophilic materials, has intrigued attention due to low synthesis condition throughout membrane preparation [18].

According to the International Union of Pure and Applied Chemistry, the term composite is defined as a multicomponent material comprising multiple, different (non-gaseous) phase domains in which at least one type of phase domain is a continuous phaseand nano-composite is defined as a composite in which at least one of the phase domains has at least one dimension of the order of nanometers [19].

Nanocomposite membranes have confirmed in many cases that they possess the ability to improve membrane efficiency in the fields of ultrafiltration [20-24], microfiltration [25-27], nanofiltration [28-30], reverse osmosis [31, 32] and forward osmosis [33-35].

Nanocomposite membranes, as its name implies, consists in a base polymer matrix and at least one filler in the nanometric domain, in general inorganic nanoparticles such as silica ( $\mathrm{SiO}_{2}$ ), carbon nanotubes (CNTs), titanium dioxide $\left(\mathrm{TiO}_{2}\right)$, aluminum oxide $\left(\mathrm{Al}_{2} \mathrm{O}_{3}\right)$, calcium carbonate $\left(\mathrm{CaCO}_{3}\right)$, silver $(\mathrm{Ag})$, zinc oxide $(\mathrm{ZnO})$, copper oxide $(\mathrm{CuO})$, iron-based nanoparticles, graphene oxide (GO) and nanozeolites have been used [24, 34, 36, 39-48] to increase the membrane performance.

For example, Balta et al. (2012) reported enhancement in terms of permeation tests, antifouling, hydrophilicity and retention through blending $\mathrm{ZnO}$ nanoparticles in PES membranes [48]. In the studies of Yang et al. (2006) reported increase in antifouling behavior, hydrophilicity, flux and porosity with the addition of $\mathrm{TiO}_{2}$ nanoparticles in the PSf membrane matrix [49].

A considerably high barrier in research for improving membrane performance is to increase all membrane properties such as retention, membrane flux and fouling decrease $[50,51]$, although frequently these procedures that enhance permeation performance will diminish the retention efficiency and vice-versa [52], thus it would be an encouraging circumstance to create a membrane that would increase membrane flux, retention and minimizing fouling simultaneously [53].

In recent years, incorporating two types of nanoparticles in the membrane matrix gained great interest in membrane fabrication. For example, Li et al. (2015) reported $\mathrm{Ag} / \mathrm{TiO}_{2}$

\footnotetext{
*email: iulian.birsan@ugal.ro; stefan.balta@ugal.ro
} 
composite membrane with enhanced hydrophilicity, flux and activity in the presence of visible light [54]. Esfahani et al. (2015) reported a decrease in contact angle and high recovery ratio when added $\mathrm{TiO}_{2}-\mathrm{MWCNT}$ in PSf membrane [55]. Kumar et al. (2016) produced a PSf-GO-TiO, membrane system with improved antifouling properties, higher hydrophilicity and good retention efficiency [56].

The presence of two nanoparticle types in the membrane matrix will lead to a new material that extends the special properties from both fillers. However, insufficient work has been done on the preparation of PSf membrane with $\mathrm{ZnO} / \mathrm{TiO}$, nanohybrid blend.

Yar et al. (2017) prepared electrospun polyacrylonitrile (PAN) nanofibrous membranes decorated with $\mathrm{TiO}_{2} / \mathrm{ZnO}$ and observed higher photocatalytic activity in the degradation of malachite green dye when compared with bare PAN, PAN-TiO, and PAN-ZnO nanofibers [57]. Bai et al. (2015) synthesized a novel UF mesoporous membrane consisting of multi-functional CNT/ZnO/TiO, nanocomposite on a CA substrate with enhanced mechanical strength, high photo-degradation capacity, high permeate flux and low fouling, also [58]. Li et al. (2017) modified PVDF membrane using atomic layer deposition thought coating TiO/ZnO on the surface and section of membranes and the results showed that the membrane with $\mathrm{TiO}_{\mathrm{V}} / \mathrm{ZnO}$ ratio of 1:3 displayed high photocatalytic activity of methylene blue degradation, low fouling, high hydrophilicity and excellent permeability compared with the control membrane [59].

In other areas of research, blending the mixed metal oxides, $\mathrm{ZnO}$ and $\mathrm{TiO}_{2}$, in the desired material showed superior properties. Agrawal et al. (2009) demonstrated that the hybrid metal oxides ( $\mathrm{ZnO}-\mathrm{TiO}_{2}$ ) is a facile approach for the fabrication of nanostructured hollow spheres used in wide range of potential applications including controlled release of the encapsulated agents, protection of the light sensitive components, artificial cells, fillers, pigments and coatings [60]. Benton et al. (2016) immobilized ZnO on the surface of $\mathrm{TiO}_{2}$ in the preparation of $\mathrm{TiO}_{2}-\mathrm{ZnO}$ catalyst nanohybrid on an activated carbon support for treatment of molasses wastewater and observed the highest photocatalytic activity, enhanced adsorption capacity as compared with the mere materials [61].

The aim of this work is to study the reliability of the option to synthesize $\mathrm{ZnO}$ and $\mathrm{TiO}_{2}$ nanoparticles blended membranes within the same polymer matrix towards improving the overall properties of membranes. The PSf membrane was fabricated with $\mathrm{ZnO} / \mathrm{TiO}_{2}$ nanoparticles by blending method. EDX was used to investigate the membrane surface composition. SEM was used to study the influence of nanoparticles over the formation behavior of membrane pores. The surface membrane hydrophilicity was characterized by contact angle measurements. Pure water flux, permeability, relative flux, retention of Congo Red dye and porosity measurements were also conducted in this article.

\section{Experimental part}

\section{Materials and methods}

Polysulfone (PSf, average Mw 35000), 1-methyl-2pyrrolidone (NMP, $\mathrm{C}_{5} \mathrm{H}_{0} \mathrm{NO}, 99 \%$ ), zinc oxide nanoparticles $(\mathrm{ZnO} \mathrm{NPs},<50 \mathrm{~nm})$, titanium dioxide nanoparticles $\left(\mathrm{TiO}_{2}\right.$ $<100 \mathrm{~nm}$ ) were supplied from Sigma-Aldrich and used without further modifications. The non-woven polyester support layer (Novatexx 2471) was kindly supplied from Freudenberg (Winheim, Germany).

\section{Membrane fabrication}

Both control PSf membrane and nanocomposite membranes were obtained through phase inversion. ZnO, $\mathrm{TiO}_{2}$ nanoparticles and $\mathrm{ZnO} / \mathrm{TiO}_{2}$ nanohybrid (weight ratio of $1^{2}: 1$ ) were added in NMP solvent with different weight percentages $(0.1,0.5$ and $1 \mathrm{wt} . \%)$ under continuous stirring for $1 \mathrm{~h}$, then PSf with $25 \mathrm{wt} . \%$ was dissolved in the dope solution and stirred for $24 \mathrm{~h}$ for a homogeneous solution. The dope solution was afterwards casted on a non-woven support layer using $250 \mu \mathrm{m}$ thickness casting knife and a film applicator (PA-2101, BYC-Gardner GmbH) with a constant casting speed. The resulted thin films were then immersed in a non-solvent bath (distilled water) $[62,63]$. The formed membranes (table 1) were washed and stored in distilled water, until they were used as samples for characterization.

Table 1

MEMBRANE COMPOSITION BY CONCENTRATIONS AND TYPE OF NANOPARTICLES

\begin{tabular}{|c|c|c|}
\hline $\begin{array}{c}\text { Membrane } \\
\text { Name } \\
\text { ** }\end{array}$ & $\begin{array}{l}\text { Nanoparticle } \\
\text { type, size }\end{array}$ & $\begin{array}{c}\text { Nanoparticle } \\
\text { concentration } \\
\text { [wt. } \% \text { ] }\end{array}$ \\
\hline Control_PSf & - & - \\
\hline Ti_0.1 & \multirow{3}{*}{$\mathrm{TiO}_{2},<100 \mathrm{~nm}$} & 0.1 \\
\hline Ti_0.5 & & 0.5 \\
\hline Ti_l & & 1 \\
\hline Zn_0.1 & \multirow[t]{3}{*}{$\mathrm{ZnO},<50 \mathrm{~nm}$} & 0.1 \\
\hline Zn_0.5 & & 0.5 \\
\hline Zn_1 & & 1 \\
\hline $\mathrm{Zn} / \mathrm{Ti}{ }^{\prime} 0.1^{*}$ & \multirow{3}{*}{$\begin{array}{l}\mathrm{ZnO},<50 \mathrm{~nm} \\
\mathrm{TiO}_{2},<100 \mathrm{~nm}\end{array}$} & 0.1 \\
\hline $\mathrm{Zn} / \mathrm{Ti}{ }^{2} 0.5^{*}$ & & 0.5 \\
\hline $\mathrm{Zn} / \mathrm{Ti} \mathbf{l}^{*}$ & & 1 \\
\hline
\end{tabular}

*The weight ratio of $\mathrm{ZnO} / \mathrm{TiO}_{2}$ nanoparticles blend is $1: 1$ for all concentrations; ${ }^{* *}$ The polysulfone concentration is $25 \mathrm{wt} \%$ for all studied membranes.

\section{Membrane characterization}

For a better understanding of the effects of $\mathrm{ZnO}, \mathrm{TiO}_{2}$ and also $\mathrm{ZnO} / \mathrm{TiO}_{2}$ nanoparticles on the membrane performance, the membranes were characterized in terms of surface and cross-sectional structure and elemental composition, porosity, water affinity (contact angle) and roughness.

\section{Morphology}

The morphology of the samples, top surface and crosssection, was investigated using FEI Quanta 200 Scanning Electron Microscope, equipped with EDX elemental composition analyzer at an accelerator voltage of $15 \mathrm{kV}$ and $25 \mathrm{kV}$. To observe the cross-section, the membrane was fractured after immersion in liquid nitrogen to obtain a clean cut cross-section. All samples were coated with gold by sputtering before observation.

\section{Porosity}

Porosity was measure through gravimetric method using equation 1.

$$
\varepsilon(\%)=\frac{W_{w}-W_{d}}{V \rho} \times 100
$$

where $W_{w}$ and $W_{d}$ are the masses of membrane samples, in wetted and dry state $(g) ; V$ is the membrane volume $\left(\mathrm{cm}^{3}\right)$, and $\rho$ is the density of water $\left(\mathrm{g} / \mathrm{cm}^{3}\right)$. The membranes were immersed in water for $24 \mathrm{~h}$ prior to the 
measurement of water saturation state. To minimize the error, the average value of 3 separate measurements is reported as the membrane porosity.

\section{Contact angle}

The surface hydrophilicity of the prepared PSf nanocomposite samples was evaluated by measuring the contact angle between the polymer surface and water droplet using a contact angle goniometer (OCA 15EC, DataPhysics). The dropping was repeated several times and the mean value was reported for the contact angle of each sample.

\section{Roughness}

Roughness analysis was determined with Image software [64] using SEM images of membrane surfaces, specifically with the plugin of this software, SurfChar]. The method in determining roughness values is through detecting the gray levels given by SEM images, after the images were converted to 32bit, darker gray depicting valleys and pores, respectively, and the brighter levels of gray representing peaks of the membrane surface. The values were listed in table 3 , all the values are expressed in pixel. This method was tested successfully by other researchers [45, 65-67]. For the visual membrane surface roughness, a $5 \mu \mathrm{m} \times 5 \mu \mathrm{m}$ area was chosen from each topview SEM image and converted from two-dimensional (2D) to three-dimensional (3D) images using the ImageJ plugin entitled Interactive 3D Surface Plot. Same parameters were used for all samples.

Also, a portable surface roughness $2 \mathrm{D}$ tester Surftest S) 210 (Mitutoyo, Japan) was used to study the membrane surface roughness for a higher scale. The analyzing length was $4 \mathrm{~mm}$ and 5 measurements were made for each membrane, following afterwards to average the remaining values.

\section{Membrane permeation performance}

Membrane performance is reported in terms of mechanical stability, pure water flux, permeability, retention, relative flux and relative flux reduction.

\section{Pure water flux and permeability}

Pure waterflux and pure water permeability were carried out with a dead-end stirred cell (Sterlitech HP4750) with a total volume of $300 \mathrm{~mL}$ and an active membrane surface area of $14.6 \mathrm{~cm}^{2}$. The pressure source of the cell was with nitrogen gas pressurized tube.

The pure water flux $\left(\mathrm{L} / \mathrm{m}^{2} \mathrm{~h}\right)$ was measured the following equation:

$$
J_{w}=\frac{V}{A \times t}
$$

where $V$ is the volume of permeate water $(L), A$ is the effective membrane area $\left(\mathrm{m}^{2}\right)$ and $\mathrm{t}$ is the permeation time (h).

Permeability ( $L / \mathrm{m}^{2} \mathrm{~h}$ bar) was calculated as a linear progression of the pure water flux and pressure ratio with the following equation:

$$
P W P=\frac{J_{w}}{\Delta p}
$$

where $\Delta p$ is the operating pressure (bar).

Water permeability experiments were carried out with pure water at an operating pressure ranging between 10 and 16 bar at room temperature (approx. $25^{\circ} \mathrm{C}$ ).

Retention of Congo red dye
The dye of choice is Congo red with a molecular mass of $696.665 \mathrm{~g} / \mathrm{mole}$, insoluble in water. The dye concentration is determined spectroscopically using a UVVis Spectrophotometer HACH DR 5000 (Hach Lange $\mathrm{GmbH}$, Germany).

The retention ratio was calculated by the following equation:

$$
\text { Retention }(\%)=\left(1-\frac{c_{f}}{c_{0}}\right) \times 100
$$

where $\mathrm{C}_{0}$ represents dye concentrations in feed solution $(100 \mathrm{ppm})$ and $\mathrm{C}_{\mathrm{f}}$ is the permeate concentration.

\section{Relative flux and relative flux reduction}

The fouling resistance of the control and modified membranes are characterized by relative flux, RF, and is calculated as follows:

$$
R F=\frac{J_{r}}{J_{w}}
$$

where $J_{r}$ is the retention flux of Congo red dye.

Relative flux reduction, RFR, is calculated as follows:

$$
R F R=\left(1-\frac{J r}{J w}\right) \times 100
$$

Tensile strength and elongation

Mechanical strength of polysulfone and mixed-matrix membranes was measured by testing the tensile-strength and elongation-at-break of a membrane specimen $(2 \mathrm{~cm}$ $\times 13 \mathrm{~cm}$ ) with a mechanical testing instrument (Instron 8850 , Norwood, Massachusetts, USA). All the tensile tests were carried out at a constant tensile speed of $5 \mathrm{~mm} / \mathrm{min}$ until breakage at room temperature.

\section{Results and discussions}

Morphology analysis of membranes

The role of nanoparticles in the process of forming polymeric membranes is that of pore formation both at the surface of the membranes and in structure, also [68].

The SEM top-view images in figure 1 show that the ZnOblended membranes have a more uniform distribution of pores. ZnO-blended membranes show a nanoparticle agglomeration on the surface and beneath the surface layer, whereas the $\mathrm{TiO}_{2}$-blended membrane does not have this particularity. An explanation could be that the decrease in nanoparticle size (in our case: ZnO NPs, $50 \mathrm{~nm}$ ) will lead to increase in agglomeration [68].

Figure 2 shows the SEM top-view images of the control membrane and the nanohybrid membrane types. The ZnO/ $\mathrm{TiO}_{2}$ membranes have a tendency of nanoparticle agglomeration on the surface but also beneath the surface, similar to the ZnO-blended membranes, but not so prominent, meaning that the Zn/Ti-type membranes share both properties of the nanoparticles in the matrix.

Comparing the control membrane with the composite membranes, especially $\mathrm{ZnO} / \mathrm{TiO}_{2}$-type membranes, a decrease in pore size and also an increase in pore density is observed. A decrease in pore size leads to higher retention and an increase in pore number produce a higher permeability [55]. The results of this study confirm this theory with the SEM images (figs. 1 and 2) and the permeability and retention chart (fig. 9).

Figure 3 exhibit the membrane morphology in crosssection and it is observed that the nanocomposite membranes have a thinner skin layer compared with the control membrane. The addition of nanoparticles generates an increase in porosity and size of macrovoids, also. According to Rahimpour et al. (2008) the composite membranes comprise in larger macrovoids due to the 


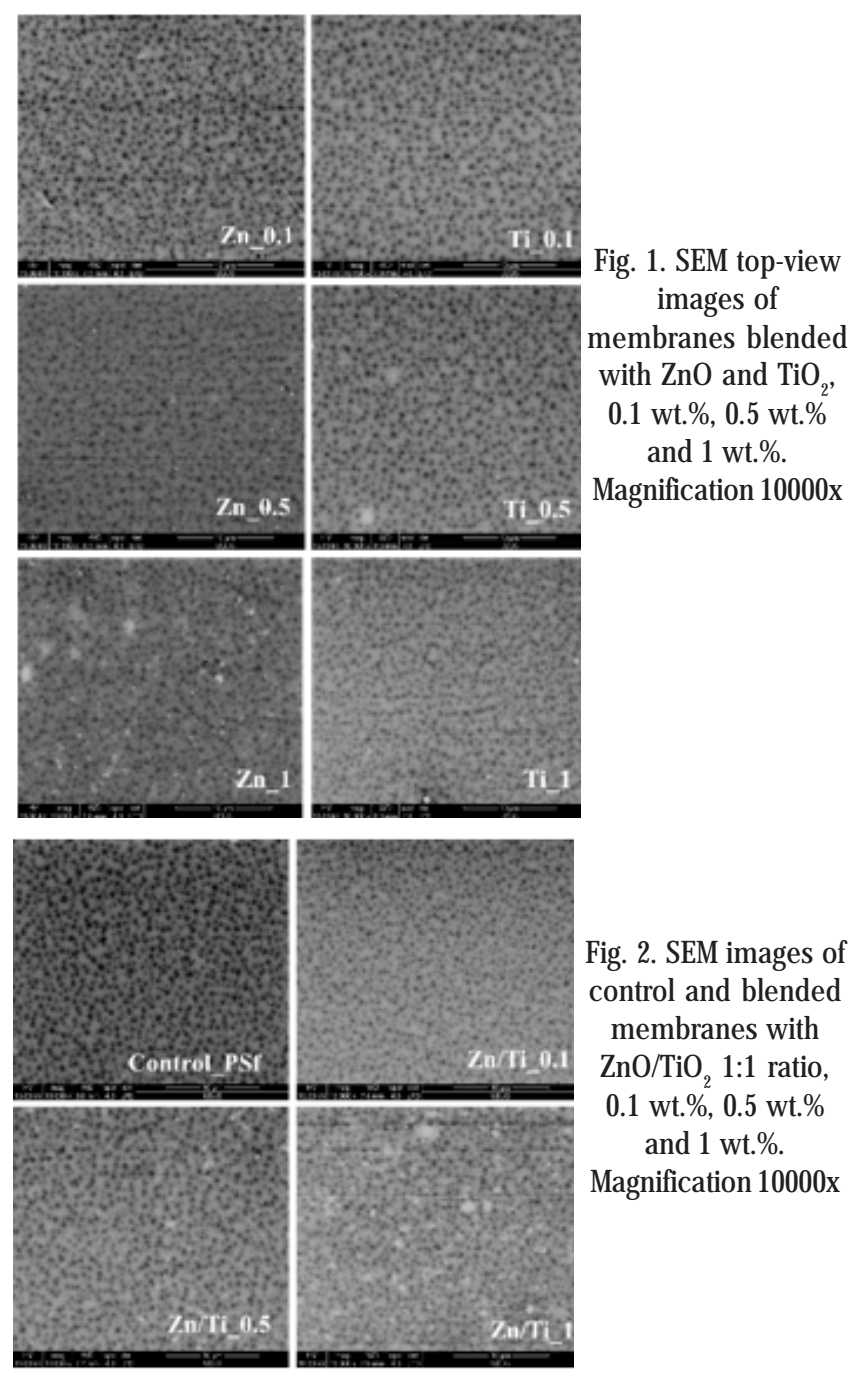

solvent-nonsolvent exchange in the phase inversion process, which is less active in the presence of nanoparticles [69]. When compared with the neat membrane, the composite membranes show thicker skin layer and the macrovoid space is increasing with nanoparticle increment, allowing water to pass through the membrane more rapidly.

\section{Analysis of EDX}

Table 2 and 3presents the EDX weight percentage values for elements which are very accurate with the real concentrations used for membrane fabrication. Moreover, for the nanohybrid-blended membrane we see that the concentration of $\mathrm{ZnO}$ nanoparticles is approximately 2 times higher than $\mathrm{TiO}_{2}$ nanoparticles.
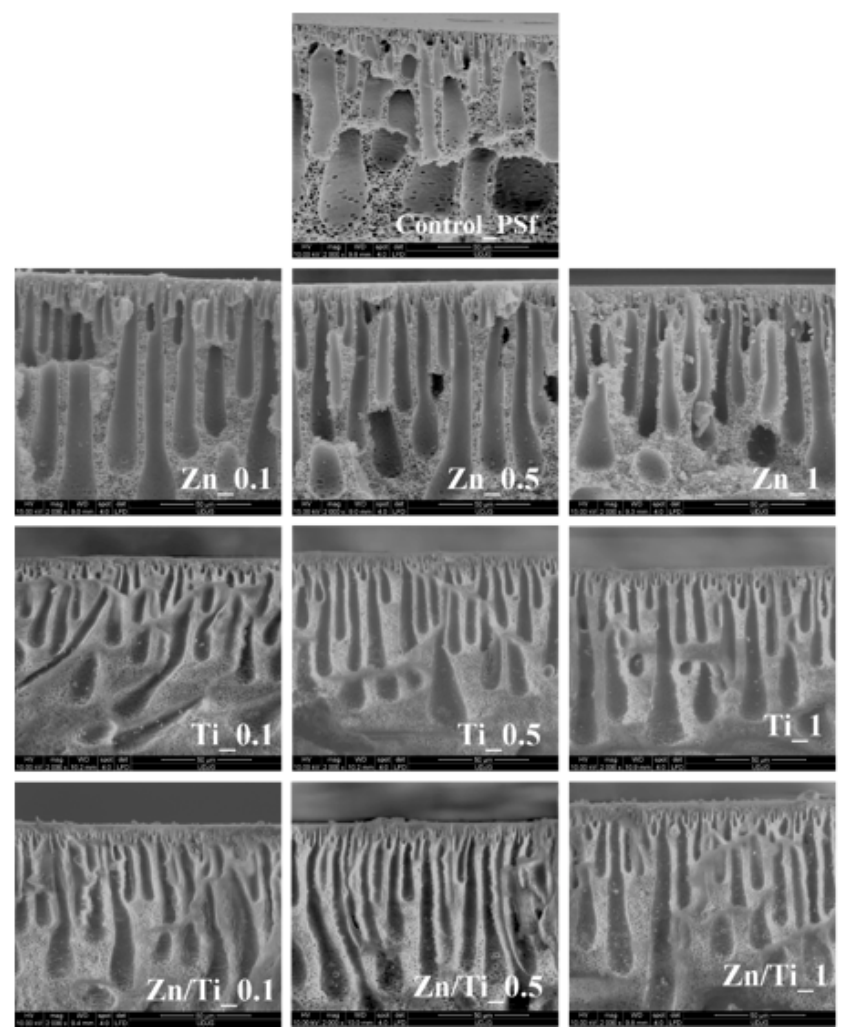

Fig. 3. Cross section SEM images for control and composite membranes. Magnification 2000x

Relating to their sizes, ZnO nanoparticles being 2 times smaller than $\mathrm{TiO}_{2}$ nanoparticles, the distribution of $\mathrm{ZnO}$ NPs in the cross-section and top-view of the membranes is higher than the $\mathrm{TiO}_{2} \mathrm{NPS}$, confirmed by figure 4 .

The most important phenomenon we notice regarding the nanohybrid $\mathrm{ZnO} / \mathrm{TiO}_{2}$ distribution in the membrane matrix (fig. 5), is that there is no presence of ZnO NPs in the areas of $\mathrm{TiO}_{2} \mathrm{NPs}$ agglomeration, probably because the interactions between nanoparticles, with respect to Van der Waals forces, is weak.

These distinctive types of nanoparticles were in repulsive state during the membrane formation process. In the case of singular-nanoparticle membrane (fig. 4, (B) and (C)), areas of the polymer with absence in nanoparticles remain because of their agglomerating property (fig. 6 (A) and (B)), leading to weaker performance. The weak attraction forces between the two types of nanoparticles in the same membrane matrix will cause one of the nanoparticle types to occupy that crude polymer space (fig. $6(\mathrm{C})$ ), resulting in a much higher homogeneity of the nanoparticles in the studied polymer. Essentially, this could be an explanation of the very high performance of the $\mathrm{ZnO}-\mathrm{TiO}_{2}$ membrane type, which will be discussed later in this study.

Table 2

TOP-VIEW EDX ELEMENTAL ANALYSIS OF NEAT AND COMPOSITE MEMBRANES, EXPRESSED IN wt.\%.

\begin{tabular}{|c|c|c|c|c|c|c|c|c|c|c|}
\hline Element & Control_PSf & Zn_0.1 & Zn_0.5 & Zn_l & Ti 0.1 & Ti 0.5 & Ti_l & Zn/Ti 0.1 & $\mathrm{Zn} / \mathrm{Ti} 0.5$ & Zn/Ti l \\
\hline $\mathrm{C}$ & 84.23 & 84.01 & 85.11 & 83.66 & 84.45 & 83.91 & 83.66 & 84.15 & 84.05 & 81.99 \\
\hline 0 & 10.96 & $11.07^{-}$ & 10.67 & 11.01 & 10.81 & $11.10^{-}$ & 10.88 & 10.48 & 10.86 & 11.61 \\
\hline $\mathrm{S}^{-}$ & 4.81 & $4.69^{\circ}$ & 3.51 & 4.05 & 4.65 & $4.75^{-}$ & $4.77^{\circ}$ & 5.06 & 4.61 & 4.60 \\
\hline $\mathrm{Zn}$ & - & 0.23 & 0.71 & 1.28 & - & - & - & 0.21 & $0.37^{-}$ & 1.29 \\
\hline $\mathrm{Ti}$ & - & - & - & - & 0.09 & 0.24 & 0.69 & 0.11 & 0.12 & 0.51 \\
\hline
\end{tabular}

Table 3

CROSS-SECTION EDX ELEMENTAL ANALYSIS OF NEAT AND COMPOSITE MEMBRANES, EXPRESSED IN wt.\%

\begin{tabular}{|c|c|c|c|c|c|c|c|c|c|c|}
\hline Element & Control_PSf & Zn_0.1 & Zn_0.5 & Zn_l & Ti 0.1 & Ti 0.5 & Ti_l & $\mathrm{Zn} / \mathrm{Ti} 0.1$ & $\mathrm{Zn} / \mathrm{Ti} 0.5$ & $\mathrm{Zn} / \mathrm{Ti}[$ \\
\hline $\mathrm{C}$ & 84.69 & 81.79 & 81.17 & 80.53 & 84.84 & 83.16 & 83.60 & 82.74 & 82.73 & 81.11 \\
\hline 0 & $8.81^{\circ}$ & 10.62 & 11.12 & 11.71 & 10.32 & 10.47 & $9.04^{-}$ & 8.46 & 12.13 & 9.12 \\
\hline $\mathrm{S}^{-}$ & 6.50 & $7.07^{-}$ & 6.71 & 5.81 & $4.74^{-}$ & $5.38^{-}$ & 6.06 & $8.32^{\circ}$ & 4.58 & 7.09 \\
\hline $\mathrm{Zn}^{-}$ & - & 0.52 & 1.00 & $1.95^{-}$ & - & רירטים & - & 0.31 & 0.42 & $1.92^{\circ}$ \\
\hline $\mathrm{Ti}^{-}$ & - & - & - & $=$ & 0.10 & 0.99 & $1.30^{\circ}$ & 0.18 & $0.14^{-}$ & 0.76 \\
\hline
\end{tabular}





Fig. 4. EDX spectra and mapping for

(A) control PSf and composite

membranes with (B) $1 w t . \% \mathrm{ZnO}$,
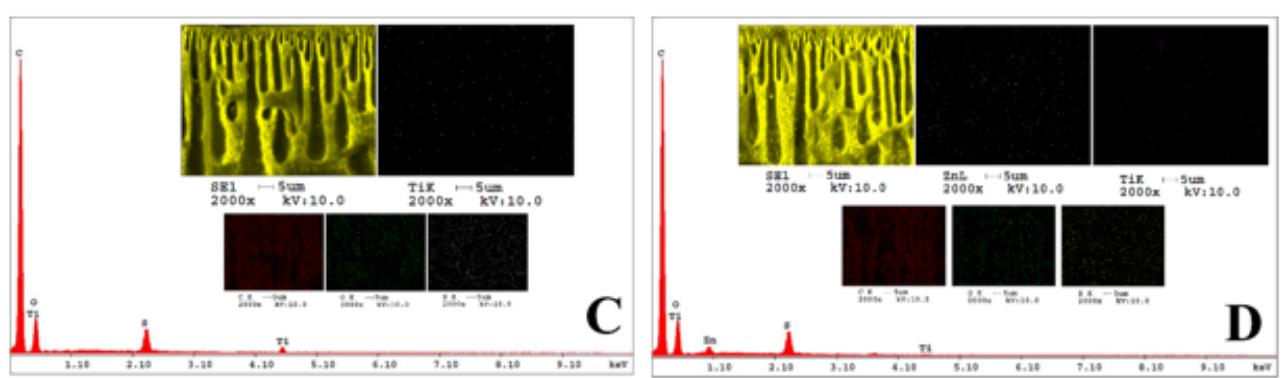

(C) 1 wt.\% TiO 2 and (D) 1 wt.\% ZnO/

$\mathrm{TiO}_{2}$ 1:1 weight ratio
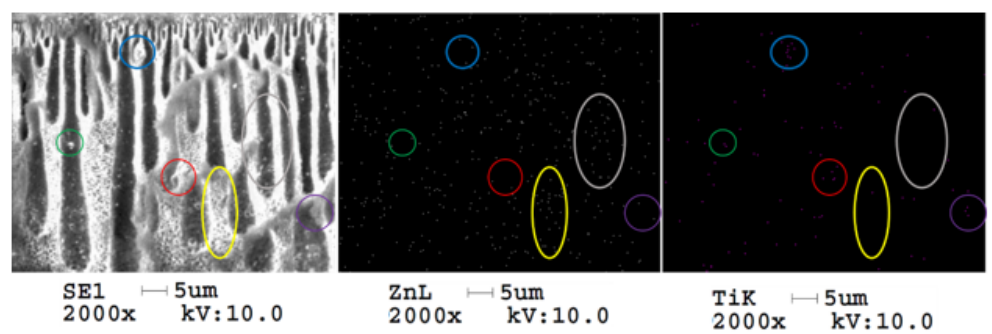

Fig. 5. $\mathrm{ZnO} / \mathrm{TiO}_{2}$ nanoparticles distribution in the polysulfone membrane (mapping collected from 1 wt.\% $\mathrm{ZnO} / \mathrm{TiO}_{2}$ nanohybrid membrane)

In order for the membranes to be considered thoroughly nanocomposites, the distance between the nanoparticles must not exceed a definite diameter of influence that gives the final material the desired properties. Larger distances between the fillers lead to the occurrence of defective areas of the composite material. Also, these defective areas, in lack of nanoparticle presence, are more prawn to fouling.

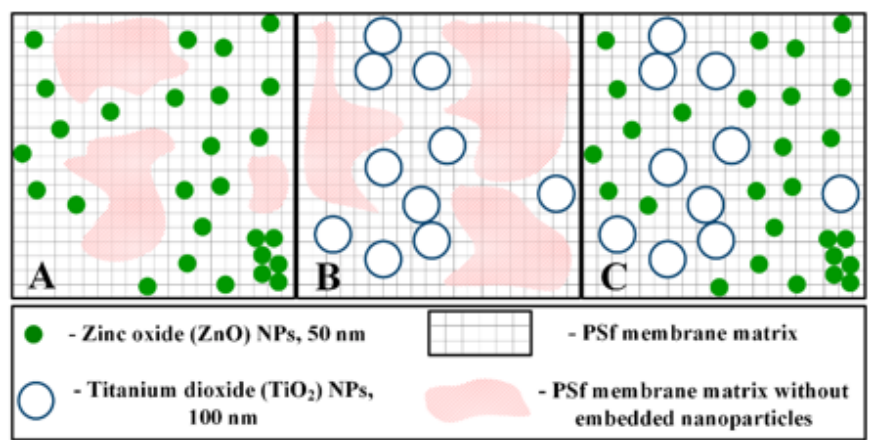

Roughness analysis

Table 3 shows the surface roughness of the fabricated membranes. Generally, lower surface roughnesses indicate superior antifouling property [70].

Analyzing table 4 it is observed that the addition of nanoparticles in the membrane matrix lead to surface roughness decrease. The lowest surface roughness is at $0.5 \mathrm{wt} . \% \mathrm{ZnO}$ nanoparticles blended membrane. Further addition of nanoparticles leads to roughness increase due to nanoparticles agglomeration tendency, phenomenon approved by other authors, also [71,72].

Even on a larger scale of the rugosimeter's action, the same roughness tendency is observed in table 5 . Adding nanoparticles above the $0.5 \mathrm{wt}$.\% threshold the roughness increases.

In figure 7 it can be seen, from the 3D graphs, that 0.5 wt.\% ZnO membrane has obviously the lowest peak value and the distance between the peak and bottom is smaller than other samples.

Fig. 6. Schematic diagram regarding the dispersability of the PSf-ZnO (A), PSf-TiO $(B)$ and

$\mathrm{PSf}-\mathrm{ZnO} / \mathrm{TiO}_{2}(\mathrm{C})$ membrane systems

\section{Table 4}

SURFACE ROUGHNESS ANALYSIS OF THE MEMBRANES BY IMAGE) (ALL UNITS IN PIXEL)

\begin{tabular}{|c|c|c|c|c|}
\hline Membrane & $\begin{array}{c}\text { Rq: root mean } \\
\text { square } \\
\text { deviation }\end{array}$ & $\begin{array}{c}\text { Ra: } \\
\text { arithmetical } \\
\text { mean deviation }\end{array}$ & $\begin{array}{c}\text { Rv: lowest } \\
\text { valley }\end{array}$ & $\begin{array}{c}\text { Rp: } \\
\text { highest } \\
\text { peak }\end{array}$ \\
\hline Control_25 & 23.5 & 18.8 & -79.5 & 76.3 \\
\hline $\mathbf{Z n} \mathbf{0 . 1}$ & 21.5 & 17.4 & -84.1 & 99.5 \\
\hline Ti_0.1 & 19.8 & 15.5 & -114.4 & 51.9 \\
\hline $\mathrm{Zn} / \mathrm{Ti} 0.1$ & 16.3 & 12.6 & -94.1 & 49.2 \\
\hline Zn_0.5 & 14.6 & 11.1 & -81.5 & 104.7 \\
\hline Ti_0.5 & 18.4 & 14.4 & -96.1 & 76.0 \\
\hline $\mathrm{Zn} / \mathrm{Ti} \_0.5$ & 19.8 & 15.4 & $-100.5^{-}$ & 74.9 \\
\hline Zn_l & 17.5 & 13.0 & -88.9 & 95.5 \\
\hline Ti_l & 16.8 & 13.1 & -94.2 & 68.1 \\
\hline $\mathrm{Zn} / \mathrm{Ti} \mathbf{1}$ & 20.1 & 15.6 & -106.6 & 62.4 \\
\hline
\end{tabular}

http://www.revmaterialeplastice.ro 
Table 5

SURFACE ROUGHNESS ANALYSIS OF THE MEMBRANES OBTAINED WITH THE MITUTOYO ROUGHNESS TESTER

\begin{tabular}{|c|c|c|c|}
\hline Membrane & $\mathbf{R a}[\mu \mathrm{m}]$ & $\mathrm{Rq}[\mu \mathrm{m}]$ & $\mathbf{R z}[\mu \mathrm{m}]$ \\
\hline Control_25 & 0.354 & 0.520 & 5.660 \\
\hline Zn_0.1 & 0.296 & 0.392 & 4.238 \\
\hline Ti_o.1 & 0.287 & 0.395 & 4.253 \\
\hline $\mathrm{Zn} / \mathrm{Ti} 0 . \mathbf{1}$ & 0.275 & 0.371 & 4.090 \\
\hline $\mathrm{Zn}$-0.5 & 0.241 & 0.345 & $3.720^{\circ}$ \\
\hline Ti_0.5 & 0.264 & 0.418 & 4.013 \\
\hline $\mathrm{Zn} / \mathrm{Ti} 0.5$ & 0.247 & 0.482 & 3.840 \\
\hline Zn_l & 0.312 & 0.428 & 3.947 \\
\hline Ti_l & 0.300 & 0.440 & $3.640^{\circ}$ \\
\hline $\mathrm{Ti} / \mathbf{Z n} \mathbf{l}$ & 0.345 & 0.500 & 4.860 \\
\hline
\end{tabular}

Also, the surface of the $0.5 \mathrm{wt} \% \mathrm{ZnO}$ membrane is more even and smooth than other samples as well. Thus, it could be concluded that the membrane casted by using the polymer solution blended with $0.5 \mathrm{wt} \% \mathrm{ZnO}$ nanoparticles have the smoothest surface. Adding 1 wt.\% nanoparticles in membrane matrix causes an increase in roughness due to nanoparticle agglomeration. The $\mathrm{ZnO}$-blended membranes exhibit higher roughness than $\mathrm{TiO}_{2}$-blended
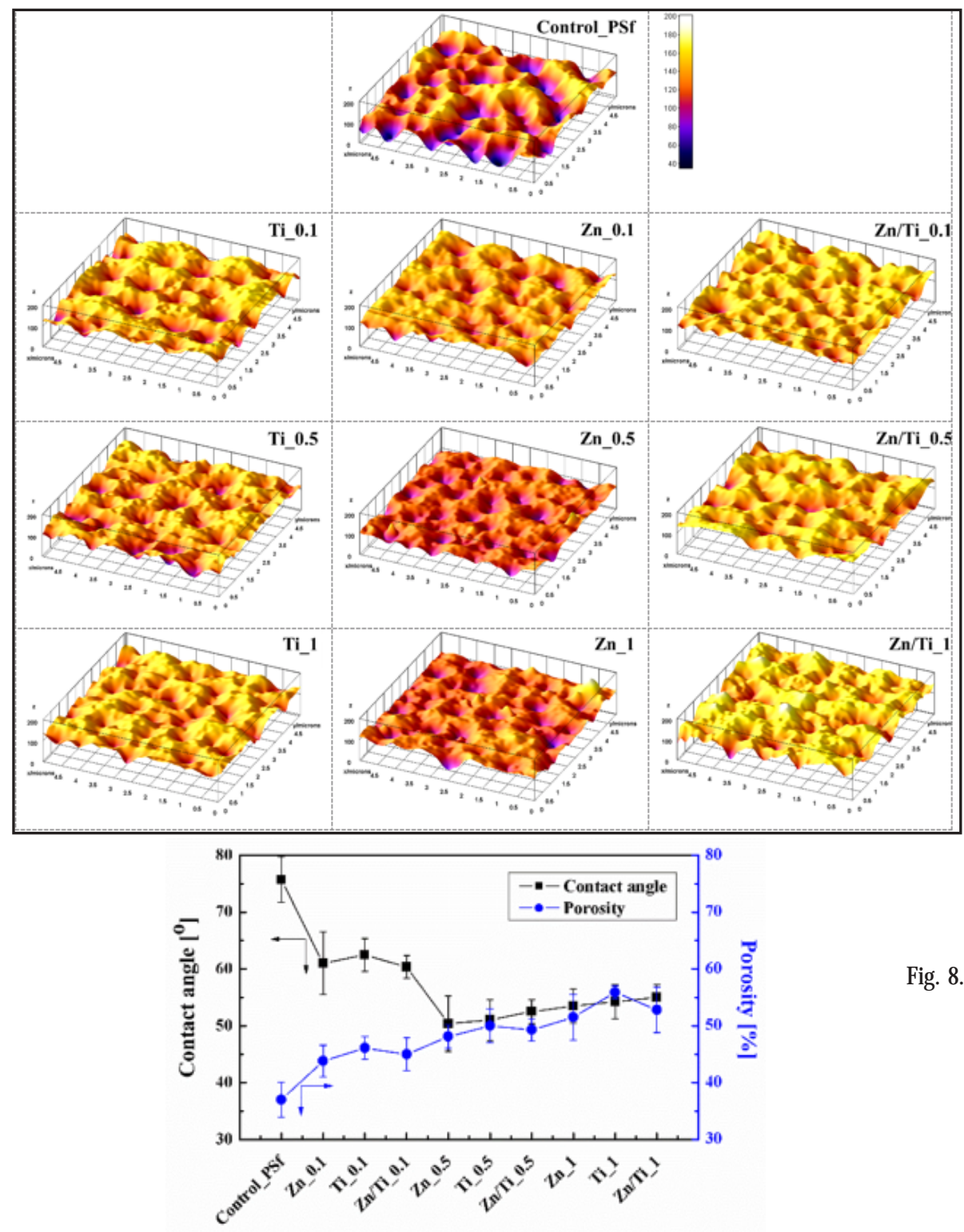

Fig. 8. Contact angle and porosity for control and composite membranes
Fig. 7. Three dimension graphs of the intensities of pixels in a color scale for the control and nanocomposite membranes
Contact angle and porosity analysis of membranes Figure 8 indicates that the contact angle, which is a good criterion for evaluation of membrane hydrophilicity, This is due to higher affinity of nanoparticles to water [25, , 48, 49]. angle of the PSf membranes decreased significantly with concentration.

As reported by Baghbanzadeh et al. (2015), which interpreted the roughness data (in this study, table 3) together with contact angle data, hydrophilicity is more dependent on roughness and not by membrane surface proportional with contact angle. In the present study, roughness is starting to increase after $0.5 \mathrm{wt}$ \% nanoparticle with the above stated. Similar results were observed at different concentrations of nanoparticle by other authors, also $[26,74]$. 


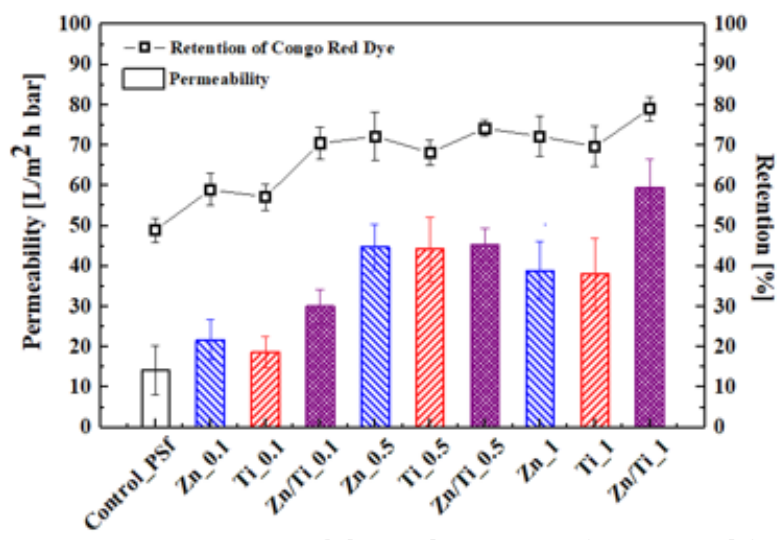

Fig. 9. Pure water permeability and retention of Congo Red for control and blended membranes. Error bars were calculated based on 3 independent replicate tests

Correlating the porosity with the cross sectional SEM images we conclude that nanoparticle addition will lead to porosity increase.

\section{Membrane permeation tests}

Distilled water permeability and retention of Congo Red

Results from the distilled water permeability experiments are displayed in figure 9 . The nanoparticles used in this study regardless of concentration or type, had a positive influence on the membranes as compared to the control membrane. Membrane retention increases with the addition of nanoparticles.

Analyzing the permeability chart (fig. 9) and SEM topview images (fig. 1 and fig. 2) we can observe that the control membrane pores are larger, in theory would mean a higher flux, but the flux chart shows the opposite. An explanation would be that the finger-like pores inside the membrane are thin and are prawn to block or narrow these pores with the applying of 10 bar pressure, resulting in its very low flux. Aligning the above mentioned with the low porosity (fig. 8) of the control membrane, it can be said that the explanation is viable.

Even at very low concentrations of nanoparticles it is observed that permeability and retention increases considerably if compared with the control membrane. However, blending $\mathrm{ZnO} / \mathrm{TiO}$ with $0.1 \mathrm{wt}$ \% in the PSf membrane improve permeability by $121.43 \%$ and retention by $44.9 \%$ over the control membrane, higher than the singular-blended membranes.

In the case of singular-blend membranes, adding nanoparticles to the casting solution up to $0.5 \mathrm{wt} . \%$, the permeability increases, due to enhanced hydrophilicity and porosity, also. Flux elevation is also a result of great distribution of nanoparticles in the casting solution leading to increased hydrophilicity. Permeability decrease after threshold limit $(0.5 w \mathrm{t} . \%$, ) is due to aggregation of nanoparticles in pores and viscosity increment of casting solution resulting in delay in the phase inversion process [75].

With addition of $1 \mathrm{wt} . \% \mathrm{ZnO}$ and $\mathrm{TiO}_{2}$, a decrease in permeability occurs, down to $39.4 \mathrm{~L} / \mathrm{m}^{2} \mathrm{~h}^{2}$ bar and $37.9 \mathrm{~L} /$ $\mathrm{m}^{2} \mathrm{~h}$ bar, respectively. Similar observations inorganic or organic additive concentration effects on membrane performance have been previously reported [66, 75-77].

In the case of $\mathrm{Zn} / \mathrm{Ti}$ nanohybrid membrane, further addition of $1 w t \% \mathrm{ZnO} / \mathrm{TiO}_{2}$ nanoparticle mixture produces a linear increase in permeability, possibly due to higher dispersion of nanoparticles that was explained earlier.



Fig.10. Relative flux for control and composite membranes

Relative flux

Relative flux is an important instrument of characterizing the antifouling ability of membranes.

Because of increased hydrophilicity and also low roughness of membranes with nanoparticle addition, the adsorptive interaction between the pollutants and the membrane surface can be mitigated. The highest relative flux was achieved by Zn/Ti 0.5 nanohybrid membrane.

Comparing the nanohybrid $\mathrm{ZnO} / \mathrm{TiO}_{2}$ membranes with the single nanoparticle blended membranes, it can be noticed that these have the highest relative fluxes, with respect to nanoparticle concentration. For example, even at the lowest concentration of nanoparticles, the $\mathrm{ZnO} / \mathrm{TiO}_{2}$ type membranes show an increase in relative flux from below 0.4 for $\mathrm{Zn} 0.1$ membranes up to approximately 0.6 in the case of Zn/Ti 0.1 membranes. As stated above, the weak attraction forces between the two types of nanoparticles lead to a more active surface of the membrane, offering the nanohybrid membrane a satisfactory antifouling tendency.

Relative flux reduction

Figure 11 shows the relative flux reduction of the membranes. Relative flux reduction is an important membrane investigation tool for finding the membrane with the lowest value that depicts high antifouling ability.

As expected, the control PSf membrane has the highest fouling with $83 \%$, while the $\mathrm{Zn} / \mathrm{Ti}$ type membranes show a relative flux reduction of 45,25 and $34 \%$ for $\mathrm{Zn} / \mathrm{Ti}-0.1, \mathrm{Zn} /$ $\mathrm{Ti} 0.5$, and $\mathrm{Zn} / \mathrm{Ti} 1$ respectively.

The slightly increase in RFR is strongly correlated with the contact angle and roughness tests, being directly proportional with the last mentioned. Similar results were obtained by other authors, also [71, 78].

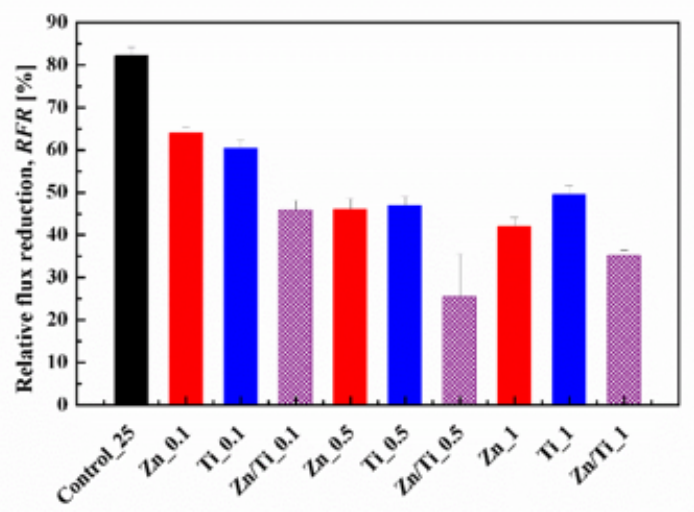

Fig. 11. Fouling resistance for control and composite membranes

Tensile strength and elongation at break

The testing results of mechanical stability including tensile stress and break elongation are listed in Ttble 6. 
The tensile stress and break elongation of control PSf membrane is $27.6 \mathrm{MPa}$ and $48.9 \%$. The mechanical stability enhances with the increase of the filler concentration, especially, at $0.1 w t . \%$ and 0.5 wt. $\%$ nanoparticles, tensile stress reach a peak value of 30.7 $\mathrm{MPa}$ following a decline with the further increase of nanoparticle concentration.

The downfall behavior of the $1 \mathrm{wt} . \%$ nanoparticle or nanohybrid increment is explained by the nanoparticle aggregation that could generate disorderly dispersions in the polymeric matrix, accordingly leading to weakening the mechanical stability of membranes. Yang et al. (2007) made similar observations for $\mathrm{PSf} / \mathrm{TiO}_{2}$ blend UF membranes [79].

\section{Table 6}

MECHANICAL STABILITY FOR CONTROL AND NANOCOMPOSITE MEMBRANES

\begin{tabular}{|c|c|c|}
\hline & $\begin{array}{c}\text { Tensile strength* } \\
{[\mathrm{MPa}]}\end{array}$ & $\begin{array}{c}\text { Elongation at break } \\
{[\%]}\end{array}$ \\
\hline Control_25 & 27.6 & 48.9 \\
\hline Zn_0.1 & 29.7 & 49.2 \\
\hline Ti_0.1 & 29.6 & 51.6 \\
\hline $\mathrm{Zn} / \mathrm{T} \mathbf{i} 0.1$ & 30.0 & 46.5 \\
\hline Zn_0.5 & 29.5 & 48.5 \\
\hline $\mathrm{Ti} 0.5$ & 29.0 & 39.4 \\
\hline $\mathrm{Zn} / \mathrm{T} \mathbf{i}_{0} \mathbf{0 . 5}$ & 30.7 & 38.4 \\
\hline Zn_l & 28.9 & 40.6 \\
\hline Ti_l & 27.9 & 40.8 \\
\hline $\mathrm{Zn} / \mathrm{Ti}$ & 26.7 & 40.0 \\
\hline
\end{tabular}

* Ultimate tensile strength of nonwoven fabric $=24.2 \mathrm{MPa}$ and elongation at break $=50.4 \%$

The $\mathrm{Zn} / \mathrm{Ti} 0.5$ membrane show the highest tensile strength $(30 . \overline{\mathrm{MPa}})$ and the lowest elongation at break $(38.4 \%)$, meaning that this dosage causes the membrane to enter a more plastic deformation domain, while the other membranes tend towards elastic structure. According to Li et al. (2009), this reason of mechanical differences at higher nanoparticle concentration (in this study, 0.5 wt.\%) is due to the possibility of creating a stronger interaction through crosslinking between nanoparticles and polymer chain, strengthening these chains resulting in a higher energy requirement in order to rip the bond between polymer and nanoparticles [30].

From the above results, the membrane mechanical property changes are mainly due to structure change arising from the modification of nanoparticles dosage or type of nanoparticles. In order to obtain membranes with better mechanical properties, the dosage and type of nanoparticles should be taken in consideration.

The results of the $\mathrm{ZnO} / \mathrm{TiO}$ nanohybrid membranes are considerably higher compared to control and singular blended membranes, with promising overall performances. Goh et al. (2015) acknowledged harmoniously that incorporating nanometric particles into the polymer will initiate new polymer/nanomaterial interfacial areas due to their quantum dimensions with a highly active surface that reshapes the fundamental properties of nanocomposites [68]. The addition of two types of nanoparticles into the polymeric matrix leads to the creation of a nanocomposite with stronger polymer chains bound by nanomaterials.

\section{Conclusions}

The hybrid membranes exhibit superior hydrophilicity, higher permeability and excellent retention in contrast with the control PSf membrane. Mixing $\mathrm{ZnO}$ and $\mathrm{TiO}_{2}$ nanoparticles with $1 \mathrm{wt} . \%$ and 1:1 weight ratio in $25 \mathrm{wt} . \%$ PSf membrane appears as the most promising range in order to improve the membrane properties. In terms of morphology, the surface of the $\mathrm{ZnO} / \mathrm{TiO}_{2}$ type membranes shows smaller pores with better distribution even at very low concentrations of nanoparticles. The nanoparticle blended membranes can drop the contact angle significantly from 76p (control PSf membrane) to about $50 \mathrm{p}$ (Zn 0.5 membrane). Further increase in nanoparticle concentration does not change considerably the contact angle. The lowest surface roughness is at $0.5 \mathrm{wt} . \% \mathrm{ZnO}$ nanoparticles blended membrane followed by the $\mathrm{ZnO} /$ $\mathrm{TiO}_{2}$ type membranes. The highest retention is obtained with the 1 wt. $\% \mathrm{ZnO} / \mathrm{TiO}_{2}$ membrane with a value of $79 \%$, while the control membrane shows a retention of only 48 $\%$. In terms of relative flux, all three concentrations of $\mathrm{ZnO} /$ $\mathrm{TiO}_{2}$ blended membranes exhibits higher antifouling properties compared to singular-blended membranes, especially $0.5 \mathrm{wt}$. $\%$ and $1 \mathrm{wt} . \%$ nanoparticle concentrations. Same tendency was reported in the relative flux reduction tests. The $0.5 \mathrm{wt} . \% \mathrm{ZnO} / \mathrm{TiO}$ membrane shows the highest mechanical stability. Due to weak van der Waals attractions between $\mathrm{ZnO}$ and $\mathrm{TiO}_{2}$ nanoparticles, dispersion was more effective compared with the mere $\mathrm{ZnO}$ and $\mathrm{TiO}_{2}$ membranes, meaning that there is no need for a dispersing agent in the membrane manufacturing industry, leading to a higher cost-efficient product. The repulsive interactions between the two types of nanoparticles lead to better nanoparticle distribution in the membrane matrix, creating a new category and clearly improved nanohybrid membranes.

\section{References}

1. FICAI (MANZU), D., FICAI, A., VOICU, G., VASILE, B.S., GURAN, C., ANDRONESCU, E., Mat. Plast., 47, no.1, 2010, p. 24

2. BOLONG, N., ISMAIL, A.F., SALIM, M.R., RANA, D., MATSUURA, T., J. Memb. Sci., 331, 2009, p. 40-49.

3. BODALO, M.T.A., GOMEZ, J.L., GOMEZ, E., LEON, G., Desalination, 168,2004 , p. 277-282.

4. AHMAD, A.L., ABDULKARIM, A.A., OOI, B.S., ISMAIL, S., Chem. Eng. J., 223, 2013, p. 246-267.

5. MULDER, M., Basic Principles of Membrane Technology, Kluwer Academic Publishers, Dordrecht, 1996, ISBN 978-94-009-1766-8.

6. PASCU, D.E., NECHIFOR, A.C., PASCU (NEAGU), M., TRAISTARU, G.A., BUNACIU, A.A., PASCU, L.F., TOTU, M., Rev. Chim.(Bucharest), 66, no.3, 2015, p. 451

7. HAN, J., LEE, W., CHOI, J. M., PATEL, R., MIN, B.R., J. Memb. Sci., 351, 2010, p. 141-148.

8. BAKER, R. W., Membrane Technology and Applications, 2nd Ed., John Wiley \& Sons Ltd, 2004, ISBN 9780470020395.

9. NUNES, S. P., PEINEMANN, K. V., Membrane Technology: In The Chemical Industry, 2nd Ed., WILEY-VCH Verlag GmbH \& Co., 2006, ISBN 978-3-527-31316-7.

10. SHABAN, M., ABDALLAH, H., SAID, L., HAMDY, H.S., KHALEK, A.A., Chem. Eng. Res. Des., 95, 2015, p. 307-316.

11. AVRAM, E., COZAN, V., Mat. Plast., 45 no.3, 2008, p. 241

12. POPA, G.A., ENACHE (POPA), D.F., TANCZOS, S.K., CIOCANEA, A.,

Mat. Plast., 54 no.4, 2017, p. 726

13. KIM, J.H., KIM, C.K., J. Memb. Sci., 262, 2005, p. 60-68.

14. CHERYAN, M., Ultrafiltration and Microfiltration Handbook, Technomic Publishing Company, Lancaster, USA, 1998. 
15. VATANPOUR, V., MADAENI, S.S., MORADIAN, R., ZINADINI, S., ASTINCHAP, B., J. Memb. Sci., 375, 2011, p. 284-294.

16. RATA, D., PASARE, L.V., ALBU, B.G., RADU, M., Mat. Plast., 47 no.1, 2010, p. 48

17. CUCIUREANU, A., BATRINESCU, G., BADEA, N.N., RADU, D.A., NECHIFOR, G., Mat. Plast., 47 no.4, 2010, p. 416

18. GENNE, I., KUYPERS, S., LEYSEN, R., J. Memb. Sci., 113, 1996, p. 343-350.

19. IUPAC. Compendium of Chemical Terminology, 2nd Ed. (The Gold Book). Compiled by A. D. McNaught and A. Wilkinson. Blackwell Scientific Publications, Oxford (1997).

20. BURUIANA, D.L., ITICESCU, C., TIRON, G.L., PINTILIE, S., SIMIONESCU, C.S., BARNAURE, M., BALTA, S., Mat. Plast., 52, no.4, 2015, p. 608.

21. ABDALRAHEEM AL ANI, H.N., CIMBRU, A.M., TRISCA-RUSU, C., TANCZOS, S.K., CUCIUREANU, A., NECHIFOR, A.C., Rev. Chim. (Bucharest), 68, no. 2, 2017, p. 203

22. AHMAD, A.L., MAJID, M.A., OOI, B.S., Desalination, 268, 2011, p. 266-269.

23. RAHIMPOUR, A., J AHANSHAHI, M., KHALILI, S., MOLLAHOSSEINI, A., ZIREPOUR, A., RAJAEIAN, B., Desalination, 286, 2012, p. 99-107. 24. WANG, Q., WANG, X., WANG, Z., HUANG, J., WANG, Y., J. Memb. Sci., 442, 2013, p. 57-64.

25. LI, J. F., XU, Z. L., YANG, H., YU, L.Y., LIU, M., Appl. Surf. Sci., 255 2009, p. 4725-4732.

26. WU, G., GAN, S., CUI, L., XU, Y., Appl. Surf. Sci., 254, 2008, p. 70807086.

27. MAXIMOUS, N., NAKHLA, G., WAN, W., WONG, K., J. Memb. Sci., 341, 2009, p. 67-75

28. JIN, L.M., YU, S.L., SHI, W.X., YI, X.S., SUN, N., GE, Y.L., MA, C., Polym. (United Kingdom), 53, 2012, p. 5295-5303.

29. SHEN, J.N., YU, C.C., RUAN, H.M., GAO, C.J., VAN DER BRUGGEN, B., J. Memb. Sci., 442, 2013, p. 18-26.

30. KUMAR, R., ISLOOR, A.M., ISMAIL, A.F., RASHID, S.A., AL AHMED, A., Desalination, 316, 2013, p. 76-84.

31. YIN, J., KIM, E.S., YANG, J., DENG, B., J. Memb. Sci., 423-424, 2012, p. 238-246.

32. FATHIZADEH, M., AROUJ ALIAN, A., RAISI, A., J. Memb. Sci., 375, 2011, p. 88-95.

33. NIKSEFAT, N., JAHANSHAHI, M., RAHIMPOUR, A., Desalination, 343, 2014, p. 140-146.

34. MA, N., WEI, J., LIAO, R., TANG, C.Y., J. Memb. Sci., 405-406, 2012, p. 149-157.

35. EMADZADEH, D., LAU, W.J. ., MATSUURA, T., ISMAIL, A.F., RAHBARISISAKHT, M., J. Memb. Sci., 449, 2014, p. 74-85.

36. PINTILIE, S.C., TIRON, L.G., BIRSAN, I.G., GANEA, D., BALTA, S., Mat. Plast., 54, no.2, 2017, p. 257

38. ENACHE, D.F., POPA, G.A., VASILE, E., RAZVAN, A., OPREA, O., VOICILA, E., DUMITRU, F., Rev. Chim.(Bucharest), 68, no.11, 2017, p. 2635

39. YU, L. Y., XU, Z.L., SHEN, H.M., YANG, H., J. Memb. Sci., 337, 2009, p. 257-265.

40. BHADRA, M., ROY, S., MITRA, S., Sep. Purif. Technol., 120, 2013, p. 373-377.

41. LIU, F., ABED, M.R.M., LI, K., J. Memb. Sci., 366, 2011, p. 97-103. 42. BEN-SASSON, M., LU, X., BAR-ZEEV, E., ZODROW, K.R., NEJ ATI, S., QI, G., GIANNELIS, E.P., ELIMELECH, M., Water Res., 62, 2014, p. 260270.

43. LIND, M.L., GHOSH, A.K., JAWOR, A., HUANG, X., HOU, W., YANG, Y., HOEK, E.M.V., Langmuir, 25, 2009, p. 10139-10145.

44. HOU, D., WANG, J., SUN, X., JI, Z., LUAN, Z., J. Memb. Sci., 405406, 2012, p. 185-200

45. EFOME, J E., BAGHBANZADEH, M., RANA, D., MATSUURA, T., LAN, C.Q., Desalination, 373, 2015, p. 47-57.
46. GANESH, B.M., ISLOOR, A.M., ISMAIL, A.F., Desalination, 313 , 2013, p. 199-207.

47. CHEN, D., ZHANG, H., HU, S., LI, J., J. Phys. Chem. C., 112, 2008, p. 117-122.

48. BALTA, S., SOTTO, A., LUIS, P., BENEA, L., VAN DER BRUGGEN, B., KIM, J., J. Memb. Sci., 389, 2012, p. 155-161.

49. YANG, Y., WANG, P., Polymer (Guildf), 47, 2006, p. 2683-2688.

50. HAUSMANNS, B.K.S., LAUFENBERG, G., J. Membr. Sci., 104, 1996, p. 95-98.

51. CATH, A.E.C.T.Y., ADAMS, V.D., J. Membr. Sci., 228, 2004, p. 5-16. 52. EMADZADEH, D., LAU, W.J ., ISMAIL, A. F., Desalination, 330, 2013, p. 90-99.

53. CHEN, X.N., WAN, L.S., WU, Q.Y., ZHI, S.H., XU, Z.K., J. Memb. Sci., 441, 2013, p. 112-119.

54. LI, J.H., YAN, B.F., SHAO, X.S., WANG, S.S., TIAN, H.Y., ZHANG, Q.Q., Appl. Surf. Sci., 324, 2015, p. 82-89.

55. ESFAHANI, M.R., TYLER, J.L., STRETZ, H.A., WELLS, M.J.M., Desalination, 372, 2015, p. 47-56.

56. KUMAR, M., GHOLAMVAND, Z., MORRISSEY, A., NOLAN, K., ULBRICHT, M., LAWLER, J., J. Memb. Sci., 506, 2016, p. 38-49.

57. YAR, A., HASPULAT, B., ÜSTÜN, T., ESKIZEYBEK, V., AVCI, A., KAMIa , H., ACHOUR, S., RCS Advances, 7, 2017, p. 29806 - 29814.

58. BAl, H., ZAN, X., ZHANG, L., DELAI SUN, D., Sep. Purif. Technol., 156, 2015, p. 922-930.

59. LI, N., TIAN, Y., ZHANG, 」., SUN, Z., ZHAO, 」., ZHANG, 」., ZUO, W., J. Memb. Sci., 528, 2017, p. 359-368.

60. AGRAWAL, M., GUPTA, S., PICH, A., ZAFEIROPOULOS, N.E., STAMM,

M., Chem. Mater., 21, 2009, p. 5343-5348.

61. BENTON, O., APOLLO, S., NAIDOO, B., OCHIENG, A., Chem. Eng. Commun., 203, 2016, p. 1443 - 1454.

62. SIMIONESCU, S., TEODORESCU, S., ION, R.M., NECHIFOR, G., Mat. Plast., 53, no.2, 2016, p. 194

63. DIMA, S.O., SARBU, A., DOBRE, T., BRADU, C., ANTOHE, N., RADU, A.L., NICOLESCU, T.V., LUNGU, A., Mat. Plast., 46, no.4, 2009, p. 372 64.*** Imagej software, ***https://imagej.nih.gov/ij/.

65. BAGHBANZADEH, M., RANA, D., MATSUURA, T., LAN, C.Q., Desalination, 369, 2015, p. 75-84.

66. CARLOS MIERZWA, J., VECITIS, C.D., CARVALHO, J., ARIETA, V., VERLAGE, M., J. Memb. Sci., 421-422, 2012, p. 91-102.

67. BAGHBANZADEH, M., RANA, D., LAN, C.Q., MATSUURA, T., Sep. Purif. Technol., 157, 2016, p. 60-71.

68. GOH, P.S., NG, B.C., LAU, W.J., ISMAIL, A.F., Sep. Purif. Rev., 44 2015, p. $216-249$.

69. RAHIMPOUR, A., MADAENI, S.S., TAHERI, A.H., MANSOURPANAH, Y., J. Memb. Sci., 313, 2008, p. 158-169.

70. HOMAYOONFAL, M., AKBARI, A., MEHRNIA, M.R., Desalination, 263, 2010, p. 217-225

71. AHMAD, A.L., ABDULKARIM, A.A., MOHD SHAFIE, Z.M.H., OOI B.S., Desalination, 403, 2017, p. 53-63.

72. SOTTO, A., RASHED, A., ZHANG, R.X., MARTíNEZ, A., BRAKEN, L., LUIS, P., VAN DER BRUGGEN, B., Desalination, 287, 2012, p. 317-325. 73. CHEN, Z., RANA, D., MATSUURA, T., YANG, Y., LAN, C.Q., Sep. Purif. Technol., 133, 2014, p. 303-312.

74. DAMODAR, R.A., YOU, S.J., CHOU, H.H., J. Hazard. Mater., 172, 2009, p. 1321-1328.

75. JAVDANEH, S., MEHRNIA, M.R., HOMAYOONFAL, M., Korean J. Chem. Eng., 32, 2016, p. 1-10.

76. ARTHANAREESWARAN, G., SRIYAMUNA DEVI, T.K., MOHAN, D., Sep. Purif. Technol., 67, 2009, p. 271-281.

77. YULIWATI, E., ISMAIL, A.F., Desalination, 273, 2011, p. 226-234.

78. J AFARZADEHA, Y., YEGANIA, R., SEDAGHAT, M., Chem. Eng. Res. Des., 94, 2015, p. 417-427.

79. YANG, Y., ZHANG, H., WANG, P., ZHENG, Q., LI, J., J. Memb. Sci., 288, 2007, p. 231-238.

Manuscript received: 15.10 .2017 